\title{
A REVIEW OF THE PERFORMANCE OF WIRELESS SYNCHRONIZED HEARING AIDS
}

\author{
Chinnaraj Geetha, Ravindran Raja Rajan, Kishore Tanniru
}

Department of Audiology, All India Institute of Speech and Hearing, Mysore, India

Corresponding author: Chinnaraj Geetha, Department of Audiology, All India Institute of Speech and Hearing, Mysore, India, e-mail: geethamysore.cs@gmail.com

\begin{abstract}
Some paired digital hearing aids use wireless technology to communicate with each other and generate improved binaural information. Coordination between the two ears makes it easier for the brain to identify sound sources and understand speech even in complex environments. How well does this technology work. This article gives an evidence-based review.

Key words: hearing aids • sound localization $\bullet$ speech intelligibility $\bullet$ wireless technology

\section{INFORMACIÓN GENERAL DE LAS PROPIEDADES DE LOS AUDÍFONOS INALÁMBRICOS SINCRONIZADOS}

\section{Resumen}

En algunos audífonos digitales emparejados se hace uso de la tecnología inalámbrica para comunicar y generar una información binarual más precisa. La coordinación entre las orejas hace que el cerebro identifique con más fácilmente el origen de los sonidos y procesa el habla incluso en entornos acústicamente complejos. Qué efectiva es esta tecnología. Este artículo es una revisión de los resultados basados en hechos.

Palabras clave: audífonos • sonido ubicación • discurso comprensible • tecnología inalámbrica

\section{ОБЗОР ПАРАМЕТРОВ СИНХРОНИЗИРОВАННЫХ БЕСПРОВОДНЫХ СЛУХОВЫХ АППАРАТОВ}

\section{Изложение}

В некоторых спаренных аналоговых слуховых аппаратах использована беспроводнвя технология для коммуникации и генерирования все более точной бинауральной информации. Координация между ушами приводит к тому, что мозг легче идентифицирует источники звуков и перерабатывает речь даже в акустически сложной среде. Насколько эффективная эта технология. Настоящая статья является обзором результатов, основанных на фактах.

Ключевые слова: слуховые аппараты • локализация звуков • внятнаяречь • беспроводные технологии

\section{PRZEGLĄD WŁAŚCIWOŚCI ZSYNCHRONIZOWANYCH BEZPRZEWODOWYCH APARATÓW SŁUCHOWYCH}

\section{Streszczenie}

W niektórych sparowanych cyfrowych aparatach słuchowych wykorzystana jest technologia bezprzewodowa do komunikacji i generowania coraz dokładniejszej informacji obuusznej. Koordynacja pomiędzy uszami powoduje, że mózg łatwiej identyfikuje źródła dźwięków i przetwarza mowę nawet w złożonym akustycznie środowisku. Jak skuteczna jest ta technologia. Niniejszy artykuł ten jest przeglądem wyników opartym na faktach.

Słowa kluczowe: aparaty słuchowe • lokalizacja dźwięków • zrozumiała mowa • technologia bezprzewodowa 


\section{Background}

Sound plays a major role in daily life. Sound conveys acoustic information which helps humans communicate with others or check on the present state of their environment. Loss of both spectral and temporal resolution is seen in people with sensorineural hearing loss $[1,2]$, creating difficulty in understanding speech in noisy backgrounds. To reach the same level of speech understanding as a normal hearing person, a hearing aid user requires an enhancement of the signal to noise ratio (SNR) of around 4-10 dB [1,3].

Advances in hearing aid technology such as digital noise reduction algorithms (DNR), adaptive directionality, and other advanced digital signal processing (DSP) techniques help the hearing aid work well in noisy situations and thus provide better SNR [4]. In individuals with normal hearing sensitivity, binaural hearing plays a major role in understanding speech in noise due to factors such as head diffraction, binaural squelch, and interaural time differences. The same applies to hearing aid users if they use binaural amplification [5]. Experiments have shown that hearing impaired listeners wearing two hearing aids (i.e. bilateral amplification) can receive benefits from binaural hearing [6]. The rate of bilateral fitting has increased in the past few years [7], and together with advances in DSP features such as adaptive directionality and DNR, bilateral amplification contributes to hearing aid fitting success.

It has been reported that time and level differences of sound reaching the ears play an important role in helping a person understand speech in a complex listening environment. Preservation of binaural cues is said to be crucial for localization as well as speech understanding [8,5]. It has been reported that standard binaural hearing aids cannot preserve interaural time differences (ITDs) and interaural latency differences (ILDs), disrupting directionality cues and leading to poorer performance in localization as well as in speech perception in noise [9]. In order to overcome this drawback, bilateral hearing aids that coordinate and synchronize their processing through wireless communication have been introduced [10]. The new binaural wireless technology emulates the complex processes of natural hearing.

In wireless binaural hearing technology, a radio link connects the hearing aids fitted to each ear, making it possible for the two hearing aids to communicate and coordinate sound processing strategies. Through the interaction and exchange of information between the ears, it is possible for the brain to generate a clear stereophonic sound [11].

Several hearing aid manufacturers have developed hearing aids that coordinate their signal processing through wireless communication. The promise is that this new hearing aid technology, together with adaptive directionality and DNR, will lead to better speech intelligibility in dayto-day noisy situations, essentially preserving the binaural cues that are lost with basic digital hearing aids. In order to justify the cost of wireless hearing aids for individuals with hearing impairment, it is important to have strong evidence about the performance of the advanced digital signal processing algorithms contained in wireless hearing aids. Hence, it is essential to answer the question 'How well do these algorithms function in terms of the basic listening needs of individuals with hearing impairment?. The aim of this article is to give an evidence-based review of work on wireless synchronization technology.

In order to gauge the performance of wireless synchronization hearing aids and whether they benefit listeners with hearing impairment, this study included articles that measured speech recognition, localization, and/or quality measures of these wireless synchronization hearing aids over a specific period of time. Since many clinical protocols and hearing aid research employed subjective methods to gauge hearing aid benefit, subjective procedures were included in this review.

\section{Methods}

As per the five steps of evidence-based review, as given by Cox [12], research papers published in the last 10 years were included. Data base search engines - Google, Medline, and PubMed - were searched for articles specific to this review. Keywords used were: wireless synchronization hearing aids, ear to ear synchronization hearing aids, performance of wireless synchronization hearing aids, wireless synchronization, and digital signal processing algorithms. To include a study in this review, it had to meet the following criteria:

- The study used hearing aids with a wireless synchronization facility.

- Articles were limited to those published from 2005 to 2015.

- The article was published in a peer-reviewed journal or other refereed publication.

- The study included adult participants with hearing impairment and/or normal participants.

- The study's participants had mild to severe sensorineural hearing loss.

- The study employed a subjective measure of the benefit these wireless synchronization hearing aids provided.

The articles which fulfilled the above conditions were further selected. Each article from the journal database needed to have at least level 4 of evidence. Level 4 refers to non-intervention studies, cohort studies, and case control studies. There were four studies that met the criteria and hence were included in this review.

\section{Results and discussion}

The 4 key papers that emerged from this search are now discussed.

\section{Sockalingam et al. (2009)}

Sockalingam and colleagues[13] evaluated the benefit of wireless synchronization hearing aids on sound quality and localization. There were 30 participants: 14 were naive hearing aid users and the others, with mild to moderate sensorineural hearing loss, were experienced users. For evaluating sound quality, three environments (cafeteria, garden, and street) were simulated. Participants were given a rating scale to gauge naturalness and clarity. To assess localization, 8 speakers, $15^{\circ}$ apart and arranged from $0^{\circ}$ to $\pm 105^{\circ}$ were used in a sound treated room. Results showed that when 
Table 1 . Summary of studies included in review

\begin{tabular}{|c|c|c|c|c|c|c|}
\hline Study & $\begin{array}{l}\text { Number of } \\
\text { participants }\end{array}$ & $\begin{array}{l}\text { Age range } \\
\text { (years) }\end{array}$ & Hearing loss & $\begin{array}{l}\text { Experienced or } \\
\text { naive user }\end{array}$ & Method used & Results \\
\hline $\begin{array}{l}\text { Sockalingam } \\
\text { et al. (2009) }\end{array}$ & 30 & $41-81$ & $\begin{array}{l}\text { Mild- } \\
\text { moderate } \\
\text { symmetrical } \\
\text { sensorineural } \\
\text { hearing loss }\end{array}$ & $\begin{array}{l}14 \text { new and } 16 \\
\text { experienced } \\
\text { users }\end{array}$ & $\begin{array}{l}\text { - } \text { Localization } \\
\text { - Questionnaire }\end{array}$ & $\begin{array}{l}\text { Localization: } 14 \% \\
\text { better performance in } \\
\text { synch ON condition } \\
\text { Better sound quality } \\
\text { in synch ON condition }\end{array}$ \\
\hline $\begin{array}{l}\text { Kreisman } \\
\text { et al. (2010) }\end{array}$ & 36 & $39-79$ & $\begin{array}{l}\text { Mild-severe } \\
\text { symmetrical } \\
\text { sensorineural } \\
\text { hearing loss }\end{array}$ & $\begin{array}{l}18 \text { new } \\
\text { users and18 } \\
\text { experienced } \\
\text { users }\end{array}$ & - QuickSIN HINT test & $\begin{array}{l}\text { HINT led to better } \\
\text { performance. } \\
3.1-3.5 \mathrm{~dB} \text { difference } \\
\text { between QuickSIN } \\
\text { and HINT scores }\end{array}$ \\
\hline $\begin{array}{l}\text { Iman et al. } \\
(2013)\end{array}$ & 20 & $\begin{array}{l}\text { 1) Mean age } \\
\text { of normal } \\
\text { hearing } \\
\text { individuals } \\
=26 \\
\text { 2) Mean age } \\
\text { of hearing } \\
\text { impaired } \\
\text { individuals } \\
=69\end{array}$ & $\begin{array}{l}8 \text { normal } \\
\text { hearing } \\
\text { individuals } \\
\text { and } 12 \\
\text { moderate- } \\
\text { severe } \\
\text { symmetrical } \\
\text { sensorineural } \\
\text { hearing loss }\end{array}$ & Experienced & $\begin{array}{ll}\text { - } & \text { HINT } \\
\text { - } & \text { Localization }\end{array}$ & $\begin{array}{l}\text { In HINT, no significant } \\
\text { difference with and } \\
\text { without synch } \\
\text { Reduced errors } \\
\text { in front/back } \\
\text { localization by } 10.5 \% \\
\text { with synch }\end{array}$ \\
\hline $\begin{array}{l}\text { Ciorba et al. } \\
(2014)\end{array}$ & 9 & $21-27$ & $\begin{array}{l}\text { Normal } \\
\text { hearing } \\
\text { individuals }\end{array}$ & New & - $\quad$ SRT & $\begin{array}{l}\text { Wireless ON and } \\
\text { directionality } \\
\text { OFF gave best } \\
\text { performance }\end{array}$ \\
\hline
\end{tabular}

synchronization was turned on, participants made $14 \%$ less localization errors in noise than when it was off, and naturalness was better (but only in the cafe environment).

There is no mention whether the DSP algorithms were activated along with wireless synchronization or not. They simply reported that they tested the hearing aid in two conditions, one with wireless synchronization and the second without. Information regarding the use of DSP algorithms such as DNR and directionality would have thrown more light on the performance of these devices.

\section{Kreisman et al. (2010)}

A study done in 2010 by Kreisman and colleagues [10] evaluated speech intelligibility in noise (SIN) using wireless hearing aids. There were 36 participants, 18 naive hearing aid users and the other 18 experienced hearing aid users. Participants were aged 39-79 years and had mild to severe sensorineural hearing loss. A Quick SIN test was administered under two conditions. In the first, the speech babble was routed through the speakers at $+135^{\circ}$ and $-135^{\circ}$ azimuth, and in the second it was given from speakers at $\pm 45^{\circ}$ and $\pm 135^{\circ}$. All the adaptive algorithms were active. A hearing in noise test (HINT) had an additional noise condition where all 8 speakers had noise and speech was presented from $0^{\circ}$. Their results suggested that there was significantly better performance in the Quick SIN test and the HINT test when the participants were fitted with the binaural wireless technology. The newer model of hearing aid was found to be better than the older one and the results also depended on the noise condition. The difference could be due to technological differences: the two models differed in terms of technology, bandwidth, and signal processing algorithms.
Iman et al. (2013)

Iman and colleagues[14] evaluated the effect of binaural wireless technology on speech intelligibility and localization. They activated only the WDRC algorithm and not any other DSP algorithm. There were 20 participants: 8 normal hearing listeners and 12 with moderate to severe sensorineural hearing loss. The 12 participants with hearing loss were experienced hearing aid users. Speech intelligibility was assessed using the HINT procedure under 3test conditions: 1) noise presented at $90^{\circ}$ azimuth; 2) noise at $270^{\circ}$; and 3) noise presented simultaneously from $90^{\circ}$ and $270^{\circ}$. They also measured localization errors in both the front/ back and left/right dimensions. For the speech intelligibility test, their results showed no statistically significant difference between wireless on and wireless off, which contradicts the results of Kreisman et al. The explanation could be that Kriesman and colleagues activated the advanced DSP algorithms and used hearing aids with a wider bandwidth, whereas in the study by Iman et al. the participants were older and age-related cognitive deficits may have affected results.

As for HINT scores, Iman and colleagues reported that wireless synchrony neither improved nor degraded the scores. For localization errors, they reported that wireless synchronization reduced the rate of front/back confusion by $10.5 \%$ among the hearing impaired group when the sound source was broadband.

Ciorba et al. (2014)

Ciorba and colleagues[15] evaluated the benefits of hearing aids with wireless binaural synchronization using a speech in noise test. There were 9 participants and they 
had normal hearing. Stimuli consisted of Italian meaningful sentences in 13 lists played through a speaker located at $0^{\circ}$. The noise consisted of cocktail party noise delivered from $0^{\circ}, 90^{\circ}, 180^{\circ}$, and $270^{\circ}$. The stimuli were presented in three conditions: 1 ) wireless synchronization mode on and directionality off; 2) wireless synchronization off and directionality on; and 3) wireless on and directionality on. The results revealed that the wireless on and directionality off condition resulted in the best performance, followed by wireless on with microphone on, then by wireless off and microphone on. They concluded that under extremely noisy conditions, the condition of wireless on and directionality off is recommended.

A summary of all 4 studies is given in Table 1.

All studies have shown that there is a significant improvement in localization using wireless synchronized hearing aids. However, none of the studies have systematically evaluated each of the DSP algorithms, and this needs to be done. Ricketts and colleagues [16] reported that in hearing aids without wireless synchronization, directional microphones help achieve better SNR when speech originates from in front of the listener, but when speech came from elsewhere, results were not so good.
When two hearing aids process the incoming signals separately, cues for localization and speech perception in noise may be affected, particularly if separate noise reduction techniques are activated [11]. However, in hearing aids with wireless synchronization, these DSP features may be expected to result in better ILD and ITD cues. There is a need for a detailed study to assess the benefit of synchronizing DSP algorithms.

\section{Conclusions}

An evidence-based review on wireless synchronization technology (ear-to-ear synchronization) in hearing aids found four key studies. The technology generally gave superior performance, at least in some of the tasks assessed. However, for some tasks, results were mixed. The difference in performance could be due to differences in the techniques and settings of the hearing aids. Authors of the studies could disable all DSP algorithms, enable all of them, or activate only directionality. Although promising, more research is necessary to systematically study the effects of each of the advanced digital signal processing techniques in wireless synchronization hearing aids.

\section{References:}

1. Dillon $\mathrm{H}$. Binaural and bilateral considerations in hearing aid fitting. In: Hearing aids. New York, 2001; 370-403.

2. Plomp R. Auditory handicap of hearing impairment and the limited benefit of hearing aids. J Acoust Soc Am, 1978; 63: 533-49.

3. Hamacher V, Chalupper J, Eggers J, Fischer E, Kornagel U, Puder $\mathrm{H}$ et al. Signal processing in high-end hearing aids: state of the art, challenges, and future trends. EURASIP, J Appl Sig Process, 2005; 2915-29.

4. Bretoli S, Bodmer D, Probst R. Survey on hearing aid outcome in Switzerland: associations with type of fitting (bilateral/unilateral), level of hearing aid signal processing and hearing loss. Int J Audiol, 2010; 49: 333-46.

5. Wightman FL, Kistler DJ. Factors affecting the relative salience of sound localization cues. In: Gilkey RH, Anderson, TR, eds. Binaural and spatial hearing in real and virtual environments. Hillsdale, NJ: Lawrence Erlbaum Associates, 1997; 1-23.

6. Boymans M, Goverts ST, Kramer SE, Festen JM, Dreschler WA. Candidacy for bilateral hearing aids: a retrospective multicenter study. J Speech Lang Hear Res, 2009, 52(1): 130-40.

7. Marketrak SK. 25-year trends in the hearing health market. Hear Rev, 2009; 16: 12-31.

8. Hawley ML, Litovsky RY, Colburn HS. Speech intelligibility and localization in complex environments. J Acoust Soc Am, 1999; 105: 3436-48.
9. Keidser G, Rohrseitz K, Dillon H, Hamacher V, Carter L, Rass $\mathrm{U}$ et al. The effect of multi-channel wide dynamic range compression, noise reduction, and the directional microphone on horizontal localization performance in hearing aid wearers. Int J Audiol, 2006; 45: 563-79.

10. Kreisman BM, Mazevski AG, Schum DJ, Sockalingam R. Improvements in speech understanding with wireless binaural broadband digital hearing instruments in adults with sensorineural hearing loss. Trends Amplif, 2010; 14(1): 3-11.

11. Schum DJ. Communication between hearing aids. Advances for Audiologists, 2010; 10: 44-9.

12. Cox RM. Evidence-based practice as a provision of amplification. J Am Acad Audiol, 2005; 16(7): 419-38.

13. Sockalingam R, Holmberg M, Eneroth K, Shulte M. Binaural hearing aid communication shown to improve sound quality and localization. Hear J, 2009; 62: 46-7.

14. Iman I, Vijay P, Ewan M, Margaret C. Evaluation of speech intelligibility and sound localization abilities with hearing aids using binaural wireless technology. Audiol Res, 2013; 3(1): e1.

15. Ciorba A, Loroni G, Prosser S, Zattara S. Quantitative enhancement of speech in noise through a wireless equipped hearing aid. Acta Otorhinolaryngol Ital, 2014; 34: 50-3.

16. Ricketts T, Henry P, Hornsby BW. Application of frequency importance functions to directivity for prediction of benefit in uniform fields. Ear Hear, 2005; 26(5): 473-86. 